Jurnal Islamika: Jurnal Ilmu-Ilmu Keislaman p-ISSN:1693-8712 | e-ISSN: 2502-7565

Vol. 19, No. 1, Juli 2019, pp. $34-45$

\title{
Penerapan Flipped Classroom Berbasis Teknologi Informasi pada Mata Pelajaran Fiqih di MTs Al-Chusnaniyah Surabaya
}

\author{
M. Ubaidillah \\ Program Studi PAI Pascasarjana UIN Sunan Ampel Surabaya \\ e-mail: ubayubud@gmail.com
}

\begin{abstract}
ABSTRAK. E-Learning is one of the breakthroughs in education that requires information technology. Various online learning models began to be developed. For example blended learning, distance learning (distance learning) and flipped learning. Online learning is basically trying to innovate and change the paradigm in learning. One model of online learning that is currently quite a lot of learning in educational research is reverse learning. Reverse classes are learning held in class with online learning. In turning the lassroom things that are usually done in the classroom such as explaining the material, giving assignments, exercises and homework are transferred to online learning. This research was conducted with development research design. This study aims to study the differences in student learning outcomes through pretest and posttest in students and student learning outcomes also aims to determine the level of student self-confidence. The application of Information Technology-Based Flipped Classroom learning model to classroom learning outcomes and the increase in self-confidence of class VIII students in Figh Subjects in MTs AlChusnaniyah Surabaya is relatively effective.
\end{abstract}

Kata kunci: Flipped Classroom learning, Information Technology 


\section{PENDAHULUAN}

Perkembangan teknologi informasi berjalan begitu cepat dan merambah ke dalam berbagai aspek kehidupan, termasuk juga dalam dunia pendidikan. Perkembangan ini menjadikan dunia seolaholah tanpa batas. Teknologi canggih ini dikenal dengan istilah internet. Berbagai informasi, berita, fasilitas bersosial media, fasilitas perdagangan secara online, termasuk pendidikan online atau yang biasa disebut e-learning, disediakan melalui media internet.

Perkembangan teknologi yang pesat serta tersedianya internet menyebabkan seluruh lapisan masyarakat termasuk guru dan siswa dapat memperoleh informasi apa saja yang beragam secara mudah dan cepat. Terlebih dengan kepemilikan alat komunikasi yaitu smartphone yang tidak hanya dimiliki oleh kaum dewasa namun juga dimiliki kaum muda khususnya siswa SMP. Penggunaan smartphone tersebut bermanfaat dalam mencari informasi melalui internet yang dapat diakses kapan pun dan dimana pun mereka butuhkan terutama dalam mencari informasi mengenai pembelajaran.

Oleh sebab itu, untuk menunjang perkembangan teknologi serta penggunaan internet bagi siswa dalam memperoleh informasi terkait pembelajaran tersebut mengajak kita sebagai guru atau calon guru untuk lebih aktif dalam mengembangkan dan meningkatkan kompetensi dalam pembelajaran dengan mengunakan internet guna menunjang kebutuhan siswa dalam memperoleh informasi pembelajaran dengan lebih efisien.

Perkembangan pembelajaran terjadi melalui proses penerimaan informasi yang kemudian diolah dan menghasilkan sebuah output dalam bentuk hasil belajar. Dalam Zainiyati (2010) menjelaskan bahwa dalam pemrosesaninformasi terjadi interaksi antara beberapa hal, yakni interaksi dalam kondisi internal (proses kognitif dan keadaan individe), kondisi eksternal (rangsangan dari lingkungan) dan interaksi keduanya akan memperoleh hasil7belajar. Dalam proses pembelajaran mencakup keterkaitan antara informasi7verbal, kecakapan intelektual, strategi kognitif, sikap dan kecakpaan motorik.

E-Learning merupakan salah satu terobosan baru dunia pendidikan yang memanfaatkan teknologi informasi. Berbagai model pembelajaran online pun banyak dikembangkan. Misalnya blended learning, distance learning (belajar jarak jauh) dan flipped learning (Mc Knight, 2013).

Salah satu model pembelajaran online yang saat ini cukup banyak menjadi kajian dalam penelitian pendidikan adalah flipped learning. Salah satu pencetus model pembelajaran flipped learning adalah guru Kimia dari Colorado tahun 2007. Siswa-siswa kimia dikelasnya sering tidak dapat mengikuti pembelajaran di kelas karena harus mengikuti perlombaan, atau pertandingan dan even lain yang sejenis. Untuk mengantisipasi hal ini guru mengembangkan video untuk merekam pembelajaran, demontrasi, dan slide peresentasi yang ditayangkan. Rekaman ini kemudian di 
upload di YouTube sehingga siswa dapat mendownloadnya kapan saja dan dimana saja (McKnight, 2013).

Penggunaan model pembelajaran flipped learning diinterpretasikan di kelas menjadi flipped classroom. di sekolah juga diharapkan mampu membantu siswa yang mengalami kesulitan belajar, sehingga dengan penerapan model pembelajaran flipped classroom tersebut siswa yang mengalami kesulitan belajar atau tertinggal dapat mengikuti pembelajaran dengan baik dan mampu lulus dalam ujian suatu materi7pembelajaran. Permasalahan diatas menimbulkan suatu ide penelitian yaitu mengembangkan pembelajaran flipped classroom yang berbasis teknologi informasi. Tujuan penelitian ini yaitu untuk mengetahui penerapan model pembelajaran flipped classroom untuk membantu siswa MTs Kelas VIII dalam meningkatkan pemahaman dan kemampuan siswa dalam memahami materi fiqih.

\section{FLIPPED CLASSROOM}

Flipped learning merupakan salah satu model pembelajaran yang memanfaatkan teknologi informasi. Menurut McKnight (2013:4): flipped learning adalah model pembelajaran yang mengkombinasikan pembelajaran online dengan pembelajaran tatap muka. Pembelajaran online dimaksudkan untuk memberikan materi dan penjelasan serta memberikan tugas-tugas untuk nantinya dikerjakan dalam kelas tatap muka. Pada pembelajaran tatap muka dilakukan pembahasan tugas, studi kasus ataupun problem solving yang intinya mengaktifkan siswa dan memberikan pengalaman belajar secara luas atau biasa disebut SCL (Student Center Learning). Pembelajaran dengan model seperti ini akan lebih efektif karena materi pelajaran dapat diakses siswa kapan saja dan dimana saja melalui fasilitas internet.

Pembelajaran pada dasarnya tetap tatap muka namun guru dan siswa berada ditempat yang berbeda. Flipped learning juga berbeda dengan blended learning yang mengkombinasikan metode pembelajaran tatap muka dengan online learning. Metode pembelajaran bisa berupa tatap muka sehari-hari, kemudian ada beberapa komponen pembelajaran e-learning yang disisipkan, maupun sebaliknya, kebanyakan pembelajaran e-learning, lalu disisipkan metode tatap muka.

Flipped learning adalah pembelajaran yang menggabungkanm pertemuan di kelas dengan pembelajaran secara online. Dalam flipped learning hal-hal yang biasa dilakukan di dalam kelas seperti menjelaskan materi, memberikan tugas, latihan dan tugas rumah di pindahkan menjadi pembelajaran online. Prinsip dalam dalam flipped learning adalah bahwa hal-hal yang biasanya jadi tugas rumah (seperti latihan, studi kasus, problem solving dan semacamnya) lebih baik dikerjakan di kelas. Sementara mendengarkan penjelasan guru menjadi tugas rumah dalam bentuk video. Oleh karena itu pembelajaran ini dinamakan flipped learning (Herreid, 2013). 
Pelaksanan model pembelajaran flipped learning di kelas biasa disebut dengan istilah flipped classroom. Flipped classroom menjadi suatu cara yang dapat diberikan oleh pendidik dengan meminimalkan jumlah instruksi langsung dalam praktik mengajar sambil memaksimalkan7interaksi satu sama lain (Johnson, 2013). Model pembelajaran flipped classroom adalah model dimana dalam proses belajarnya siswa lebih banyak mempelajari materi pelajaran di rumah dengan mengamati video pembelajaran, sehingga kegiatan belajar mengajar di kelas lebih diefektifkan untuk pengerjaan tugas, dan diskusi tentang materi atau masalah yang belum dipahami siswa. Dengan demikian diharapkan ketika siswa mengalami kesulitan dapat langsung dikonsultasikan dengan temannya atau dengan guru sehingga permasalahannya dapat langsung dipecahkan. Bahkan siswa juga mampu menyampaikan hasil belajarnya di rumah dan didiskusikan bersama di kelas. Proses dari model pembelajaran flipped classroom dapat dilihat dari gambar berikut:

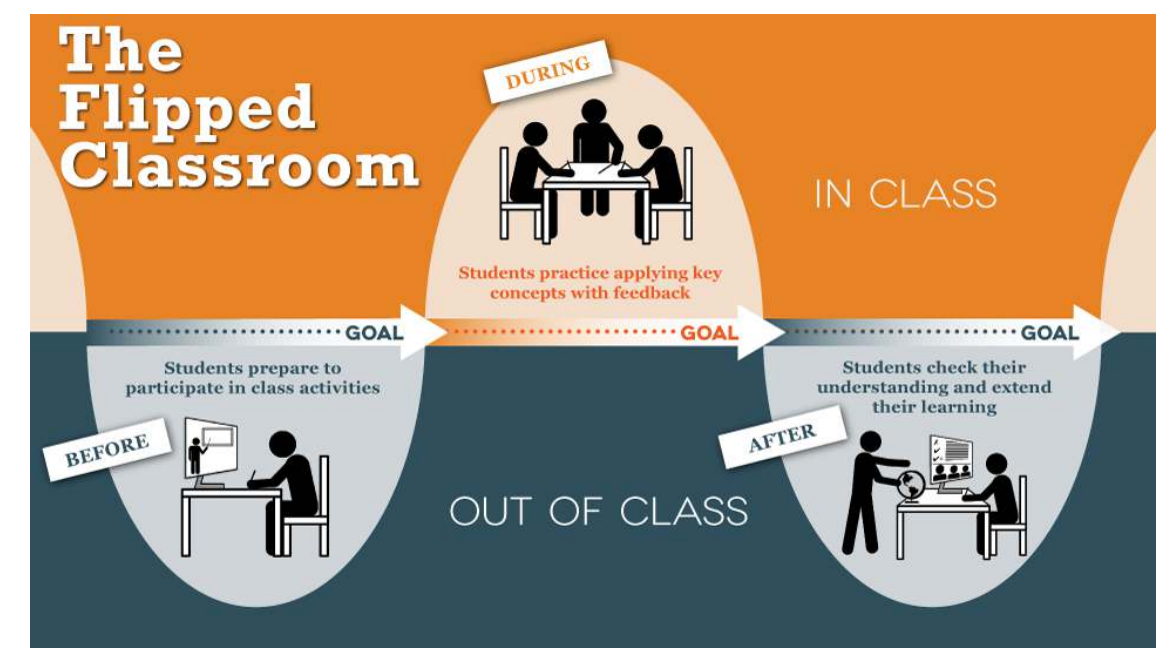

Pembelajaran di kelas dengan model flipped classroom ini akan menimbulkan pembelajaran yang benar-benar lebih bersifat student centered, karena di dalam kelas siswa akan punya lebih banyak waktu untuk menyelesaikan studi kasus, melakukan pembelajaran berbasis masalah, praktik dan berdiskusi dan mematangkan materi yang telah dipelajari di rumah.

Perkembangan flipped classroom yang dilakukan oleh guru dilihat secara profesional dengan melihat video pembelajaran dari guru, dalam pelaksanaannya pembelajarannya di kelas dapat digunakan secara lebih efektif dan kreatif, orang tua dapat melihat soal latihan, pencapaian siswa yang meningkat, sehingga menarik, siswa mampu mempelajari teori yang mendukung pada pendekatan-pendekatan yang yang baru dan manfaat dari menggunakan tehknologi adalah fleksibel dan sesuai untuk pembelajaran secara modern. 


\section{METODE PENELITIAN}

Bentuk penelitian ini termasuk ke dalam penelitian eksperimen. Adapun Jenis penelitian eksperimen ini menggunakan Quasi Experimental Design atau eksperimen semu. Bentuk rancangan quasi exsperimental yang dipakai dalam penelitian ini dengan menggunakan teori Nonequivalent Control Group Design dengan pola sebagai berikut:

\begin{tabular}{cccc}
\hline Kelas & Pretest & Perlakuan & Posttest \\
\hline $\mathrm{E}$ & $\mathrm{T}_{1 \mathrm{E}}$ & $\mathrm{X}_{\mathrm{E}}$ & $\mathrm{T}_{2 \mathrm{E}}$ \\
\hline $\mathrm{K}$ & $\mathrm{T}_{1 \mathrm{~K}}$ & - & $\mathrm{T}_{2 \mathrm{~K}}$ \\
\hline
\end{tabular}

Tabel 1. Pola Nonequivalent Control Group Design

Keterangan:

E : Kelas eksperimen

K : Kelas kontrol

$\mathrm{X}_{\mathrm{E}} \quad$ : Perlakuan kelas dengan mengunakan modelpembelajaran flipped classroom (eksperimen)

$\mathrm{T}_{1 \mathrm{~K}} \quad$ : Hasil tes awal (pretest) sebelum pembelajaran di kelas Kontrol

$\mathrm{T}_{1 \mathrm{E}} \quad$ : Hasil tes awal (pretest) sebelum pembelajaran di kelas Eksperimen

$\mathrm{T}_{2 \mathrm{~K}} \quad$ : Hasil tes akhir (posttest) setelah pembelajaran di kelas Kontrol

$\mathrm{T}_{2 \mathrm{E}} \quad$ :Hasil tes akhir (posttest) setelah pembelajaran di kelas Eksperimen

Populasi dalam penelitian ini adalah siswa kelas VIIIA dan siswa kelas VIIIB tahun ajaran 2018/2019, kelas VIIIA sejumlah 20 siswa sebagai kelas eksperimen dengan model pembelajaran flipped classroom sedangkan kelas VIIIB sejumlah 20 siswa sebagai kelas kontrol dengan model pembelajaran tradisional. Teknik pengambilan sampel yang digunakan pada penelitian ini adalah purposive sampling. Sehingga semua sampel dianggap memiliki kecerdasan yang sama. Adapun alat yang digunakan dalam pengumpulan data pada penelitian ini, yaitu tes hasil belajar (soal pretest dan posttest), lembar angket dan lembar observasi. Berikut adalah Prosedural dalam melakukan penelitian ini yang mencakup tiga tahap sebagai berikut:

\section{Tahap Awal (Persiapan)}

Tahap-tahap yang dilakukan pada tahap persiapan di kelas eksperimen antara lain: (1) Guru membuat Rencana Pelaksanaan Pembelajaran (RPP), dan menyiapkan video pembelajaran yang akan digunakan untuk pembelajaran flipped lassroom di kelas eksperimen, (2) Guru membuat instrumen penelitian berupa lembar angket kepercayaan diri siswa dan tes hasil belajar siswa yang meliputi soal pretest dan posttest (1) Guru memberikan link yutube tentang video "skema Haji dan Umrah" dan meminta peserta didik untuk mempelajari di rumah video tersebut (2) Guru 
memberikan daftar pertanyaan tentang materi Haji dan Umrah yang akan didiskusikan bersama di kelas, yang bisa dilihat dari video yang telah diberikan. Sedangkan untuk kelas kontrol guru hanya meminta peserta didik untuk mempelajari mempelajari buku paket mata pelajaran fiqih yang ada.

\section{Tahap Proses (Pelaksanaan)}

Tahap-tahap yang dilakukan pada proses pelaksanaan ini antara lain: (1) Guru Memberikan soal pretest kepada seluruh siswa kelas kontrol dan siswa kelas eksperimen. (2) Dalam pelaksananan guru mempersiapkan hal-hal yang diperlukan dalam pembelajaran di kelas eksperimen ataupun kontrol dengan materi Haji dan Umrah (3) Dalam proses pembelajaran pada kelas eksperimen menggunakan model pembelajaran flipped lassroom dengan metode diskusi, presentasi siswa, dan tanya jawab, sedangan kelas kontrol menggunakan metode tradisional yakni guru menjelaskan materi di depan kelas. (4) Guru memberikan soal posttest kepada siswa diakhir pembelajaran sekaligus memberikan angket kepeayaan diri, (5) Guru melakukan interview kepada siswa sebagai bahan observasi tingkat kepercayaan diri siswa.

\section{Tahap Akhir (Pengolahan Data)}

Tahapan yang dilakukan pada proses akhir ini antara lain: (1) Guru melakukan pengolahan dan analisis data hasil penelitian berupa nilai pretest dan posttest pada kelas kontrol maupun kelas eksperimen (2) Guru mengambil kesimpulan berdasarkan analisis data, (3) Guru menyusun laporan7penelitian.

\section{HASIL DAN PEMBAHASAN}

Prosentase hasil pretest dan posttest pada kelas eksperimen dan kelas kontrol pada pembelajaran fiqih materi haji dan Umrah, serta hasil observasi dari tingkat peraya diri peserta didik pada kelas kontrol dan kelas eksperimen dapat dilihat dari diagram berikut: 


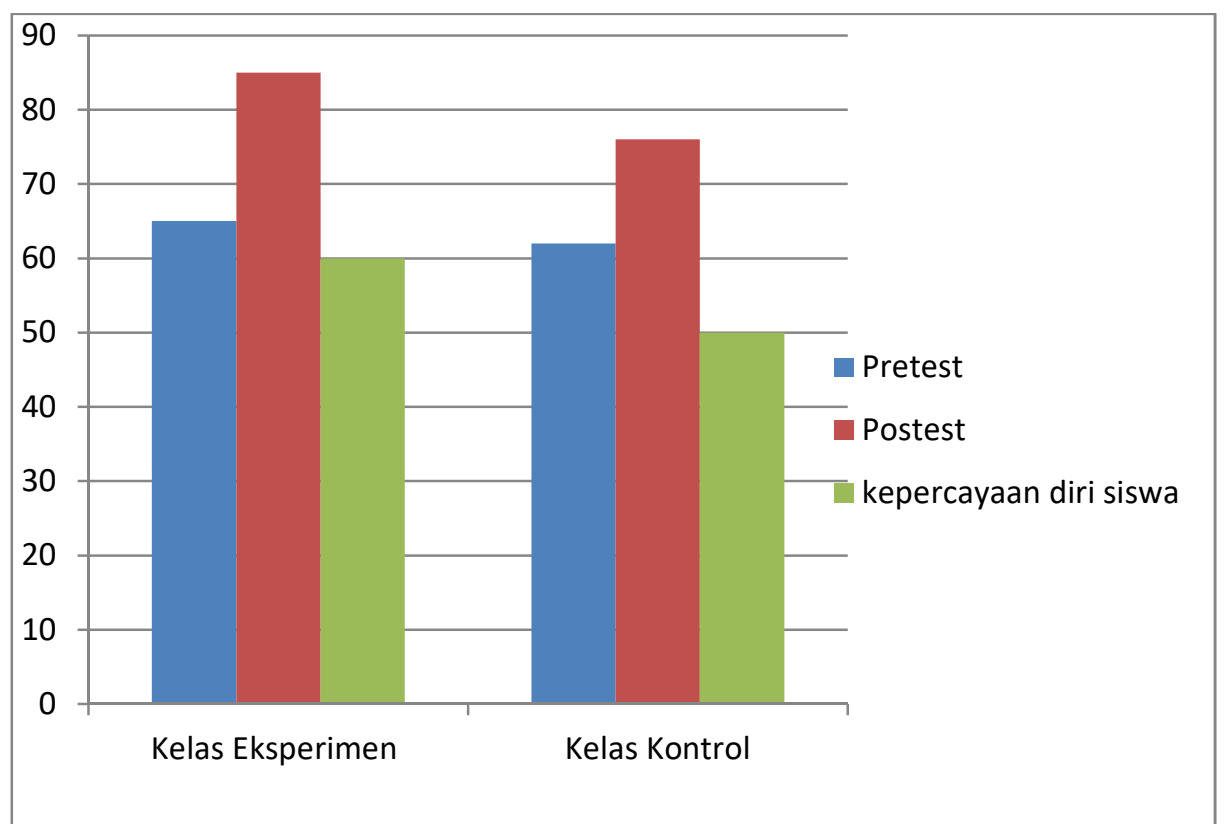

Gambar 2. Prosentase nilai pretest, posttest dan keperayaan diri siswa

Berdasarkan diagram diatas dapat dilihat bahwa rata-rata nilai pretest pada kelas eksperimen adalah 65 sedangkan untuk kelas kontrol adalah 62, jadi dapat diketahui bahwa nilai pretest kelas eksperimen lebih tinggi dibandingkan kelas kontrol, namun tidak terlampau jauh karena hanya selisih 3 point. Prosentase ketuntasan kedua kelas tersebut 0\% karena KKM pada mata pelajaran fiqih adalah 75 . Sedangkan untuk rata-rata nilai posttest pada kelas eksperimen adalah 85 sedangkan untuk kelas kontrol adalah 76, sehingga dapat diketahui bahwa nilai posttest kelas eksperimen lebih tinggi dibandingkan kelas kontrol, hal ini terlampau jauh karena selisih 9 point.

Prosentase ketuntasan untuk kelas ekperimen sebesar 100\% artinya semua siswa telah menapai KKM, sedangkan untuk kelas kontrol hanya menapai 70\% dikarenakan ada sebagian siswa yang tidak mencapai KKM. Untuk lebih jelalsnya dapat dilihat paa tabel berikut: 


\begin{tabular}{lcccc}
\hline \multirow{2}{*}{ Kelas } & \multicolumn{2}{c}{ Pretest } & \multicolumn{2}{c}{ Posttest } \\
\cline { 2 - 5 } & $\begin{array}{c}\text { Nilai rata- } \\
\text { rata }\end{array}$ & Ketuntasan & $\begin{array}{c}\text { Nilai rata- } \\
\text { rata }\end{array}$ & Ketuntasan \\
\hline Eskperimen & 65 & $0 \%$ & 85 & $100 \%$ \\
\hline Kontrol & 62 & $0 \%$ & 76 & $70 \%$ \\
\hline
\end{tabular}

Gambar 2. Prsentase ketuntasan nilai pretest dan posttest kelas eksperimen dan kelas kontrol pada materi Haji dan Umrah.

Adapun untuk prosentase dari observasi kepercayaan diri siswa melalui angket dapat dilihat dari diagram diatas bahwa pada kelas eksperimen adalah 60 sedangkan untuk kelas kontrol adalah 50, jadi dapat disimpulkani bahwa tingkat keperayaan disi siswa di kelas eksperimen lebih tinggi dibandingkan kelas kontrol. Hal ini didapat dari observasi guru ketika siswa pada kelas ekperimen berdiskusi dan berani mempresentasikan hasil diskusinya di kelas.

Penelitian ini bertujuan untuk mengetahui perbedaan hasil belajar siswa melalui pretest dan posttest pada siswa. Selain hasil belajar siswa juga berujuan untuk mengetahui tingkat keperayaan diri siswa kelas VIII di MTs Al-Chusnaniyah Surabaya pada mata pelajaran fiqih. Pada pelaksanaanya perlakuan yang diberikan pada kelas VIII berbeda, kelas VIIIA menjadi kelas ekspreimen dan kelas VIIIB menjadi kelas kontrol. Kelas eksperimen dalam kegiatan belajar mengajar mata pelajaran fiqih menggunakan model pembelajaran flipped classcoom sedangkan untuk kelas kontrol menggunakan model pembelajaran konvensional (tradisional).

Adapun untuk prosesnya kelas eksperimen menggunakan model pembelajaran flipped classcoom berbasis teknlogi informasi, yang dimaksud teknologi informasi disini adalah penggunaan sistem pembelajaran online di luar kelas, yakni dengan penayangan video pada youtube yang dapat diakses siswa dan dipelajari sebelum memulai aktivitas pembelajaran di sekolah. Dengan siswa mempelajari materi di rumah tersebut menjadikan siswa memiliki bekal pengetahuan dari rumah dan lebih yakin dan percaya diri dalam menerima pembelajaran di kelas. Sehingga akan tercipta sistem pembelajaran yang aktif dan menarik bagi peserta didik di kelas, dan akan tercipta student center learning yang baik.

Pada menelitian ini juga ditelisik tentang keperayaan diri seorang siswa, hal ini dilihat dari beberapa aspek yaitu keyakinan menjawab, optimis, kemandirian dalam belajar dan interaksi sosial. Berdasarkan hasil observasi oleh guru dan dipadukan angket keyakinan kemampuan diri peserta didik, baik kelas eksperimen maupun kelas kontrol dalam pembelajaran fiiqh mengalami peningkatan dalam pembelajaran. Peningkatan tersebut dilihat dari hasil observasi pembelajaran 
yang menunjukkan bahwa hampir sebagian besar siswa memperhatikan penjelasan guru serta menatatnya, namun tidak sedikit pula yang tidak memperhatikan.

Berdasarkan hasil wawanara kepada siswa diakhir pembelajaran didapatkan informasi bahwa mayoritas siswa terbiasa menggunakan pembelajarn tradissional. Sebagian banyak siswa lebih mudah memahami materi pembelajaran yang dijelaskan langsung oleh guru, dibanding mempelajari sendiri di rumah. Akan tetapi ada pula siswa yang merasa bosan dengan pembelajaran fiqih yang tradisional (metode ceramah) dan siswa menginginkan variasi dalam pembelajaran fiqih, misalnya saat pembelajaran diikuti ice breaking seperti kuis, games, candaan, ataupun menggunakan media seperti video pembelajaran. Rasa bosan cenderung membuat siswa tidak okus belajar dan kurang memperhatikan guru, sehingga siswa tidak dapat memahami konsep pembelajaran fiqih dengan baik.

Perbedaan yang dialami oleh siswa pada kelas kontrol dan siswa eksperimen adalah adanya pemberian materi dalam bentuk video pembelajaran yang mengharuskan siswa untuk mempelajari secara mandiri di rumah. Hal tersebut sedikit membantu siswa dalam pemahaman konsep terlebih dahulu, sehingga sehingga siswa dapat mengetahui kemampuannya.

Dengan demikian optimisme siswa pada kelas eksperimen lebih tinggi dibandingkan kelas kontrol, hal ini jelas karena siswa kelas eksperimen lebih siap dalam hal materi karena telah mempelajarinya di rumah melalui video pembelajaran, dan ketika berdiskusi dan presentasi didepan teman-temannya ia akan lebih siap dibanndingkan siswa dari kelas kontrol.

Berdasarkan hasil wawancara di kelas eksperimen yang mengggunakan model pembelajaran flipped classroom, mereka menjawab pembelajaran menjadi lebih menarik dan memudahkan siswa mempelajari fiqih materi Haji dan Umrah. Dengan video pembelajaran yang mengharuskan siswa untuk mempelajarinya secara mandiri di rumah, lebih memudahkan siswa dalam memahami konsep materi maupun pengaplikasiannya, karena siswa dapat lebih fokus dan lebih konsentrasi belajar, serta siswa dapat menghentikan dan memutar ulang video tersebut. Sesuai dengan pendapat Berret (2012) bahwa salah satu kelebihan model pembelajaran flipped classroom adalah siswa dapat mempelajari materi pelajaran dalam kondisi dan suasana yang nyaman dengan kemampuannya menerima materi. Adapun apabila masih ada materi yang belum dipahami, siswa dapat bertanya kepada guru atau teman saat tatap muka di kelas. Dengan demikian Peserta didik akan lebih optimis dalam pembelajaran fiqih di kelas. 


\section{KESIMPULAN}

Dari penjelasan diatas dapat ditarik kesimpulan bahwa Flipped learning adalah pembelajaran yang menggabungkan pertemuan di kelas dengan pembelajaran secara online. Dalam flipped learning halhal yang biasa dilakukan di dalam kelas seperti menjelaskan materi, memberikan tugas, latihan dan tugas rumah di pindahkan menjadi pembelajaran online. Adapun implementasi dari flipped learning adalah dengan model7pembelajaran flipped classroom yakni model pembelajaran yang dalam proses belajarnya siswa lebih banyak mempelajari materi pelajaran di rumah dengan mengamati video pembelajaran, sehingga kegiatan pembelajaran di kelas lebih diefektifkan untuk pengerjaan tugas, dan diskusi tentang materi atau materi yang belum dipahami oleh siswa.

Hasil belajar siswa pada penelitian ini rata-rata nilai pretest pada kelas eksperimen adalah 65 sedangkan untuk kelas kontrol adalah 62, jadi dapat diketahui bahwa nilai pretest kelas eksperimen lebih tinggi dibandingkan kelas kontrol. Sedangkan untuk rata-rata nilai posttest pada kelas eksperimen adalah 85 sedangkan untuk kelas kontrol adalah 76, sehingga dapat diketahui bahwa nilai posttest kelas eksperimen lebih tinggi dibandingkan kelas kontrol.

Adapun untuk prosentase dari observasi kepercayaan diri siswa melalui diketahui bahwa pada kelas eksperimen adalah 60 sedangkan untuk kelas kontrol adalah 50, jadi dapat disimpulkani bahwa tingkat keperayaan disi siswa di kelas eksperimen lebih tinggi dibandingkan kelas kontrol. Hal ini dikarenakan pemberian materi dalam bentuk video pembelajaran yang mengharuskan siswa untuk mempelajari secara mandiri di rumah, sehingga membantu siswa dalam pemahaman konsep terlebih dahulu, sehingga optimisme siswa ketika di kelas yang mendapat perlakuan dengan model pembelajaran flipped learning meningkat.

Sesuai penjabaran diatas maka dapat disimpulkan bahwa penerapan model pembelajaran Flipped Classroom Berbasis Teknologi Informasi terhadap hasil belajar kelas dan peningkatan keperayaan diri siswa kelas VIII pada Mata Pelajaran Fiqih di MTs Al-Chusnaniyah Surabaya tergolong efektif.

\section{SARAN}

Berpacu pada kesimpulan dan hasil penelitian yang dijelaskan diatas, beberapa saran dari peneliti perlu disampaikan antara lain: (1) Guru hendaknya memberikan pembelajaran yang tepat dan menarik untuk diterapkan dalam proses pembelajaran, terlebih menggunakan flipped classrom sehingga siswa tidak merasa bosan, (2) guru hendaknya7memberikan arahan kepada siswa sebelum menonton video pembelajaran (3) dalam hal penulisan masih banyak sekali kekurangan, seperti kurangnya uji validitas media maupun alat evaluasi siswa, (4) sekolah hendaknya lebih meningkatkan fasilitas belajar mengajar di sekolah, sehingga dapat mendukung penggunaan 
berbagai model pembelajaran khususnya model pembelajaran flipped classroom berbasis teknologi informasi.

\section{REFERENSI}

Bergmann, J., \& Sams, A. 2014. Fliped Learning: Gateway to student engagement. Learning \& Leading with Technology.

Berrett, Dan. 2012.How 'Flipping' the Classroom Can Improve the Educational

Hanif, Husni Nadya. 2016. Perbandingan antara Model Pembelajaran Flipped Classroom Berbantuan Edmodo dengan Pembelajaran Konvensional terhadap Hasil Belajar Sistem Operasi (Ekesperimen Kelas X SMK 1 Banyudono). Skripsi Universitas Negeri Sebelas Maret Surakarta.

Harimurti, S.M., 2019.7Penerapan Open Class pada Flipped Classroom Berbasis Teknologi Informasi di Mata Kuliah Pendidikan Agama Islam Prodi Farmasi FMIPA UII. Refleksi Pembelajaran Inovatif, Vol 1(1), 89-99. bttps:// doi.org/10.20885/rpi.vol1.iss1.art8

Herreid, Freeman \& Nancy A Schiller. 2013. Case Studies and The Flipped Classroom. Journal of College Science Teaching Vol. 42, No. 5

Horizons. 2011. Flipping The Classroom, Educational7Horizons, Vol. 90, No 1

Kurniawidi, Maria Pitados, Pengembangan Pembelajaran Flipped Classroom Dengan Memanfaatkan LMS Kelase Topik Menggambar Grafik Fungsi SMP Kelas VIII, Universitas Sanata Dharma, Yogyakarta, ISBN: 978-602-6258-07-6

Pratiwi, Astri dkk, Pengaruh Model Flipped Classroom Terhadap Self Confidence Dan Hasil Belajar Siswa Sman Pontianak.

Ridha, Muhammad, dkk, Jurnal PendidikanPengarub Flipped Mastery Classrom Terbadap Perolehan Hasil Belajar Kognitif Mahasiswa. Pascasarjana Universitas Negeri Malang, EISSN: 2502-471X

Slameto.72003, Belajar dan Faktor-Faktor yang Mempengarubinya. Jakarta: Rineka Cipta.

Sudjana, Nana. 2003. Penilaian Hasil Proses Belajar Mengajar. Bandung : PT Remaja Rosdakarya.

Sugiyono. 2015.7Metode 7Penelitian Pendidikan7Pendekatan7Kuantitatif, Kualitatif, dan R®D.7Bandung: Alfabeta.

Wahyuni, Esa Nur dan Baharudin, 2007, Teori Belajar dan Pembelajaran, Yogyakarta: Ar-Ruz Media Yamin, Martinis. 2009. Strategi Pembelajaran Berbasis Kompetensi. Jakarta: Gaung Persada.

Yulhendri, Tri7Kurnaiawati,7Flipped7Learning Berbasis7Web Pada Pembelajaran7Di Universitas Negeri Padang, Universitas negeri Padang

Zainiyati, Husniyatus Salamah, 2010, Model7dan Strategi Pembelajaran7 Aktif (Teori dan Praktek dalam pembelajaran PAI), Surabaya: CV Putra Media Nusantara 
Penerapan Flipped Classroom Berbasis Teknologi Informasi pada Mata Pelajaran Fiqih di MTs Al-Chusnaniyah Surabaya

Zainiyati, Husniyatus Salamah, 2017, Media Pembelajaran7Berbasis ICT, Jakarta: Kenana7Prenadamedia Grup. 